\title{
2 つの斜面安定計算法の提案
}

\section{TWO NEW SLICE METHODS FOR SLOPE STABILITY ANALYSIS}

\author{
望月秋利*·三笠正人**.勝田守文*** \\ By Akitoshi MOCHIZUKI, Masato MIKASA and Morifumi KATSUDA
}

\begin{abstract}
This paper presents newly developed two slice methods for slope stability analysis ; Advanced Limit Equilibrium method and Janbu- $h / 3$ method. They can be applied for both circular and non-circular slip surfaces. The Advanced Limit Equilibrium method gives a reasonable safety factor and a plausible distribution of interslice forces more easily than the Morgenstern \& Price method. The Janbu- $h / 3$ method gives a safety factor accurate enough for practical purposes, though it does not always give proper interslice forces.
\end{abstract}

\section{1. まえがき}

斜面の安定解析は実務において頻繁に遭遇する問題で あり, その研究は土質力学の主要な課題の 1 つとして古 くから取り組まれてきた。

斜面安定計算法のうち現在最も広く用いられているス ライス分割法の範囲でいえば, 1930 年代ペターソン

(K.E. Petterson), フェレニウス (W. Fellenius), ハルティン (S. Hultin) によって示されたいわゆるス ウェーデン法を䠢矢とすることができよう ${ }^{1), 21}$. その後 の安定計算法の発展はせん断強度の考え方亡両輪を形成 しながら進み, その成果は各種解析法の提案や斜面破壊 の事例研究として数多く報告されている．この論文では 対象を安定計算法に絞ることにする。

さてスライス分割法の発展のうえでの里程標として, スウェーデン法に続くものとして，スライス間力の考え 方を導入したテーラー (W. Taylor) の修正スウェーデ ン法 ${ }^{3)}$, ビショップ (A.W. Bishop) の解析法 ${ }^{4)}$, さら

* 正会員 工修 大阪市立大学講師 工学部土木工学科 （元558 大阪市住吉区杉本 3-3-138）

** 正会員 工博 大阪市立大学教授 工学部土木工学科 (同上)

*** 正会員 工修 基礎地盤コンサルタンツ (株) (元・同上 大学院院生）（宁550 大阪市西区鞄本町 1-15-2）
に非円弧すべり面の安定解析を可能にしたヤンブ $(\mathrm{N}$. Janbu） 法5) を挙げることができよう.モルゲンステル ンら (N.R. Morgenstern \& V.E. Price) の方法 ${ }^{6}{ }^{6}$ は 現在最も一般化された解法と評価を受けているが, 用い るつり合い式の観点からみれば基本的にはヤンブ法と同 じである.この点については本文に詳しく示すが，いず れの計算方法も不静定問題を何らかの仮定を導入するこ とによって解くことに変わりなく, したがってその仮定 が解の特性を支配する.

本論文で提案する “改良限界つり合い法”および “ヤ ンブ・ $h / 3$ 法” と名付けた, 非円弧すべり面にも適用で きる $2 つ$ 新しい計算方法も当然この制約からまぬがれ ることはできない. しかし, 前者の改良限界つり合い法 はモルゲンステルン・プライス法（以下 M \& P 法と略 す）の “合理的”之される解とほぼ同じ安全率を与え, しかもスライス間力および余剰滑動力（定義は2. に示 す), スライス間力の作用位置 (スラスト線) について, より適切に評価できるという特徴をもっている. また, ヤンブ・ $h / 3$ 法は前者に比べてわずかに安全率が大きく なり, またスライスに働く力の評価精度は劣るが, 計算 ははるかに容易なので, 非円弧すべり面に対するかなり 精度のよい実用計算法となり得ると考えられる. 


\section{2. ヤンブ・ $\boldsymbol{h} / 3$ 法と改良限界つり合い法}

説明の便宜上, ヤンブ・ $h / 3$ 法の誘導から始める $(h$ はスライス高さを意味する). 本法も従来のスライス法 と同様に，二次元平面ひずみ問題として扱うので，考え る力はすべて単位奥行当たりのものである.

\section{（1） ヤンブ・h/3 法の誘導}

図一1 は斜面のすべり土塊から取り出した 1 つのスラ イスに働くカを示したものである. 浸透流の影響はスラ イス側面，底面に働く水圧として考える. そして各スラ イスのすべり面に働く垂直力 $N$ はそれぞれのスライス の重心を通る鈆直な線とすべり面の交点 $m$ に，また間 隙水圧の合力 $U$ と $E^{* 1}$ はそれぞれの応力分布の重心位 置に作用するものとする. 地震力については震度法に基 づき, 水平震度 $k_{H}$ を考慮する.

ヤンブはスライスの水平方向と鉛直方向の力のつり合 いのほかに, $m$ 点に関するモーメントのつり合いを考 えて安全率式を導いだ イス法 (The Generalized Procedure of Slices) とよん だが，本論文では慣例にならってヤンブ法（あるいはヤ ンブの厳密法）とよぶことにする. スウェーデン法やビ ショップ法のようにすべり円弧中心に関するモーメント 式を用いていないため，ヤンブ法は非円弧形状のすべり 面にも適用できる.

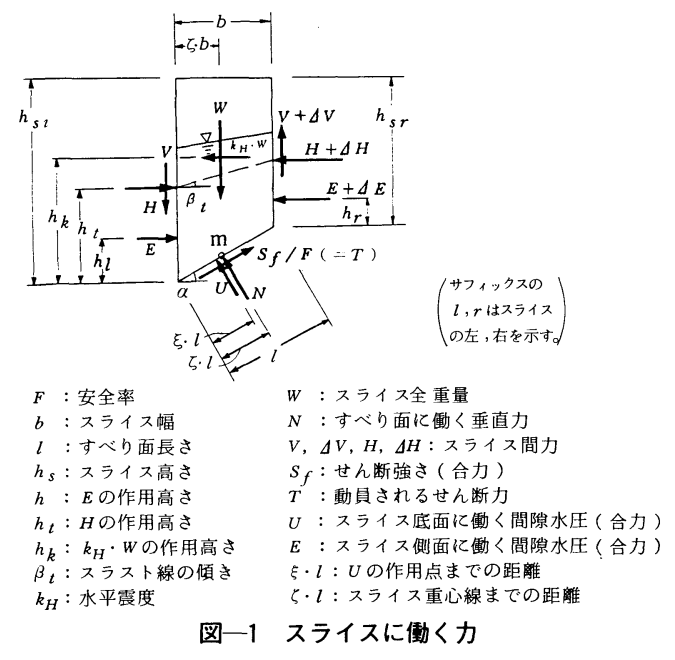

*1 圧密非排水せん断条件 (急激な破壊) での安定解析を行 う場合, 一般全応力法の立場で定義された強度定数 $c_{c u}, \phi_{c u}$ を用いるなら，せん断によって発生する間隙水圧は考慮する 必要はない (強度定数にすでに考虑されている). したがって, $U, E$ の値はせん断前の中立間隙水圧をとればよい，一方有 効応力法によって安定解析を行う場合は, せん断によって発 生する間隙水圧を含んだ $U, E$ を用い, 強度定数としては $c^{\prime}$, $\phi^{\prime}$ を用いる. 圧密排水条件で安定解析を行う場合は, せん断 中に間隙水圧は発生しないので，このような両者の区別はな $\left(^{7)}\right.$.
さて，ヤンブ法はスウェーデン法やビショップ法では 用いなかった各スライスに関するモーメント式 $n$ 個 $(n$ はスライス分割数）を加えたのでそれだけ条件式は増え るが，また新たにスライス間力の作用位置 $h_{t}$ が末知数 として $n-1$ 個増え, 結局不静定問題であることに変わ りない. そこでヤンブは $h_{t}$ に関して,$\phi$ 材料 $(c=0)$ の場合スライス高さの約 $1 / 3$ 点あるいはその近傍に，ま た $c>0$ 材料の場合, 斜面の圧縮域ではそれよりいくら か高く, 引張域ではそれよりいくらか低く，その間は両 高さを滑らかに結ぶ線上の位置を仮定することをすす め，計算例を示した ${ }^{8)}$. この仮定の仕方には任意性があ るため, 結局解と併せて検討し, 適切な仮定および適切 な解であることを判断し，用いることになる.すなわち， この手法は常に解析者の engineering judgement る必要があり, 1 つのすべり面に対して, 唯一の解を与 えるものではない。

これに対し，ここで提案するヤンブ・ $h / 3$ 法は, $c>$ 0 材料に対しても「 $h_{t}$ をスライス高さの $1 / 3$ に仮定する」 方法である*2. 一般に解の収束は容易で, 解は当然唯一 的に定まる．以下，図一1を参照してこれを誘導する． なおこれは，基本的にはヤンブの導いたものと同じ式に なるが，スライス幅が有限であることを考慮してスライ ス重量の作用位置を正しくスライスの重心位置にとった こと(これによって分割数が少なくても計算精度があま り下がらないことを確認している), また浸透力, 地震 力を考慮した点が異なっている.

まず, 安全率の定義を

$F=S_{f} / T$

とする.ここに $F$ は安全率， $S_{f}$ はすべり面上で動員可 能なせん断抵抗力の合力, $T$ は実際に動員されるせん 断力（滑動力と同じ大きさで，方向は逆）である.すべ り面方向の力のつり合いは，図一1を参照して次のよう に表わされる.

$$
S_{f} / F=(W-\Delta V) \sin \alpha+\left(\Delta H+\Delta E+k_{H} \cdot W\right) \cos \alpha
$$

すべり面に垂直な方向の力のつり合いから，次式が得ら れる.

$$
N=(W-\Delta V) \cos \alpha-\left(\Delta H+\Delta E+k_{H} \cdot W\right) \sin \alpha-U
$$

*2 ヤンブは安全率の略算方法として, 斜面形状と材料に よって決まる係数を用いる方法を提案した. この方法を Janbu's simplified method（ヤンブの簡易法）とよぶこともある が，ヤンブ自身が示したように simplified routine procedure (略算法) とよぶべきもので，本質的に厳密法とは性質を異 にするものである．著者らは，まず解を得るための条件の検 討を行い (3. (1)), ここに示した仮定を用いてよい結果を得 ることを確認した.この方法はちょうよ゙ヤンブの厳密法を簡 易化（特殊化）して解く方法すなわち，本来は簡易ヤンブ法 とよばれるべき方法である.しかし，本論文では名称の混乱 を避けるため, この方法をヤンブ・ $h / 3$ 法 (Janbu- $h / 3$ method) とよぶことにした. 
またクーロン則を，

$$
S_{f}=\left(c+\sigma_{0} \tan \phi\right) l=c \cdot l+N \tan \phi
$$

と表わしたとき, 式中 $\sigma_{0}$ は全応力からせん断強度に影 響しない静水圧や浸透流などによる中立間隙水圧を差引 いた「有効な全応力」7)である(ただし一般全応力解析 法の場合; $* 1$ 参照). 式 ( 2 )，（3）および（4）を 用い， $N, S_{f}$ は次のように表わされる.

$$
\begin{aligned}
& N=\frac{W-\Delta V-c \cdot l \sin \alpha / F-U \cos \alpha}{\cos \alpha+\sin \alpha \cdot \tan \phi / F} \\
& S_{f}=\frac{c \cdot b+(W-\Delta V-U \cos \alpha) \tan \phi}{\cos \alpha+\sin \alpha \cdot \tan \phi / F} .
\end{aligned}
$$

また, 式（2）（6）から, 水平方向のスライス間力差 $\Delta H$ は，次のように表わされる.

$$
\left.\begin{array}{rl}
\Delta H= & \frac{c \cdot b+(W-\Delta V-U \cos \alpha) \tan \phi}{F\left(\cos ^{2} \alpha+\sin \alpha \cdot \cos \alpha \cdot \tan \phi / F\right)} \\
& -\Delta E-k_{H} \cdot W-(W-\Delta V) \tan \alpha
\end{array}\right\} \cdots \cdots(7)
$$

さて, 水平方向のスライス間力については当然,

$\Sigma \Delta H=0$

が成立する. 式（7）を（8）に代入して次式を得る.

$$
\begin{gathered}
\sum\left\{\frac{c \cdot b+(W-\Delta V-U \cos \alpha) \tan \phi}{F\left(\cos ^{2} \alpha+\sin \alpha \cdot \cos \alpha \cdot \tan \phi / F\right)}\right\} \\
=\sum\left\{\Delta E+k_{H} \cdot W+(W-\Delta V) \tan \alpha\right\}
\end{gathered}
$$

安全率 $F$ はどのスライスに関しても等しいと仮定する 亡*3, 式 (9) から次の式を得る.

$$
F=\frac{\sum\left\{\frac{c \cdot b+(W-\Delta V-U \cos \alpha) \tan \phi}{\cos \alpha+\sin \alpha \cdot \tan \phi / F}\right\}}{\sum\left\{\left(\Delta E+k_{H} \cdot W\right) \cos \alpha+(W-\Delta V) \sin \alpha\right\}} .
$$

また $N$ の作用点 $m$ に関するモーメントのつり合いを 考えると， $V$ は次のように表わされる.

$$
\begin{aligned}
V= & -H \tan \beta_{t}-\frac{\Delta H}{b} h_{t}+E\left(\frac{h_{l}-h_{r}}{b}-\tan \alpha\right) \\
& -\Delta E\left\{\frac{h_{r}}{b}+(1-\zeta) \tan \alpha\right\}+U(\zeta-\xi) \frac{1}{\cos \alpha} \\
& -k_{H} \cdot W\left(\frac{h_{k}}{b}-\zeta \cdot \tan \alpha\right) \\
& -\Delta V(1-\zeta)+\Delta H\left(\zeta \cdot \tan \alpha-\tan \beta_{t}\right)
\end{aligned}
$$

ヤンブはアンダラインを付した右辺第 7,8 項を微小上 して無視した. 本法においても同様に無視し*4,「 $h_{t}$ は スライス高さの $1 / 3$ とする」という仮定を全スライス面 に対して適用する．すなわち式（11）に

$$
h_{t}=h_{s l} / 3
$$

*3この内容はすべり面上でせん断強さが同時に fullmobilize する，いわゆる全般せん断破壊が生ずるものと仮定する(す なわち進行性破壊を考慮しない）ことと同義で，現在の安定 計算法全般に用いられている仮定である.

*4 式 (11) の第 7，8 項を無視せずに計算したところ，こ れらを無視したケースに比べて安全率は $0.002 〜 0.01$ 大きく なり,収束のための繰返し回数は増えた.ヤンブ・ $h / 3$ 法では, 実用的計算法という観点から第 7,8 項を無視することにした。
を代入し，右辺第 7，8 項を省略すると，

$$
\begin{aligned}
V= & -H \cdot \tan \beta_{t}-\frac{\Delta H}{b} \cdot \frac{h_{s l}}{3}+E\left(\frac{h_{l}-h_{r}}{b}-\tan \alpha\right) \\
& -\Delta E\left\{\frac{h_{r}}{b}+(1-\zeta) \tan \alpha\right\}+U(\zeta-\xi) \frac{1}{\cos \alpha} \\
& -k_{H} \cdot W\left(\frac{h_{k}}{b}-\zeta \cdot \tan \alpha\right)
\end{aligned}
$$

となる。

すべり土塊の両端においてはスライス面の高さがゼロで あるから，

$$
\begin{array}{ll}
V_{1}=0, & V_{n+1}=0 \\
H_{1}=0, & H_{n+1}=0 \\
h_{t 1}=0, & h_{t n+1}=0 \\
E_{1}=0, & E_{n+1}=0
\end{array}
$$

が成立する（ここでサフィックスはスライス面ナンバー である).

式（14）の境界条件のもとで, 式 (10) 右辺および左 辺の $F$ が一致し, かつ式 (13) を満足した場合の諸量 が求める解となる.

図一2に計算の手順を示す。一般に解の収束は早い. 次節に示す計算例では, 収束するまでの「ループ2」（図 一2）の繰返しは通常 10 回未満で, 多くても30 回程度 であった。

\section{（2）改良限界つり合い法の誘導}

改良限界つり合い法の誘導はヤンブ・ $h / 3$ 法と同じ く, すべり土塊内の任意スライスに働く力（図一1）の すべり面方向とそれと垂直な方向のつり合い，および $N$ の作用点 $m$ に関するモーメントのつり合いを基礎式 とする安定計算法で，非円弧すべり面にも適用できる． すなわち前節の式（1 ～（11）および（14）はそのまま 用いられ，安全率は，式（10）加求められる.

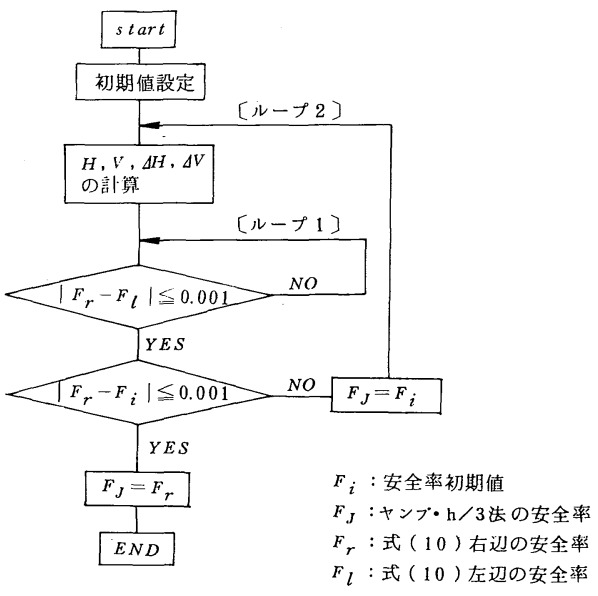

図一2 ヤンブ・ $\boldsymbol{h} / 3$ 法計算手順 
さて, 本計算法もヤンブ・ $h / 3$ 法と同様, 力学的高 次不静定問題であるから, 何らかの仮定の導入が必要で ある．本法では，“余唾骬動力の方向が，スラスト線の 方向に一致する”と仮定する。ここに余剩滑動力（左向 きに正) $\boldsymbol{F}_{r}$ は，そのスライスの両側面に働くスライス間 力を $\boldsymbol{L}, \boldsymbol{R}$ とベクトル表示するとき，

$$
\boldsymbol{L}+\boldsymbol{R}+\boldsymbol{F}_{r}=0
$$

で定義される.これから，

$$
\boldsymbol{F}_{r}=-(\boldsymbol{R}+\boldsymbol{L})=-(\Delta \boldsymbol{V}+\Delta \boldsymbol{H})
$$

と表わせる．ベクトル $\boldsymbol{F}_{r}$ はスライス間力ベクトルの和 と同じ大きさで，逆向きである (図一3参照).

すなわち，図一3（1）はスライス自らの重量（およ び地震力）に起因する滑動力が大きくて，それを自らの すべり面に働くせん断抵抗力によって支えることができ ないので, その差, すなわち余剩滑動力 $\boldsymbol{F}_{r}$ を左隣のス ライスに伝えて（厳密には右隣のスライスにもスライス 間力の減少として伝わる) 安定を保つ例を示したもので ある.したがって図（1）の $L$ は $R$ に比べて大きい. 逆に図( 2 ) は, 自らの滑動力に対する抵抗力のほかに, 右隣のスライスから伝えられる余唾滑動力に対する抵抗 力, すなわち余分に分担する抵抗力をも有している例で, このときこのスライスの余剩滑動力は図（1）のベクト ルとは逆向きとなる．また，当然

$$
\Sigma \boldsymbol{V}=0, \Sigma \boldsymbol{H}=0 \text { より, }
$$$$
\sum \boldsymbol{F}_{r}=0
$$

となる。

さて前述の $\boldsymbol{F}_{r}$ の方向についての仮定は次式のように 表わせる.

$$
\frac{\Delta V}{\Delta H}=-\tan \beta_{t}
$$

ここに， $\beta_{t}$ はこのスライス中のスラスト線が水平と成 す角度である. 式（18）の目的は各スライスの滑動抵抗 力の過不足分 $(\Delta \boldsymbol{V}+\Delta \boldsymbol{H})$ を最も自然な形で隣のスラ イスへ伝達させることにある*5.

図一 4 に改良限界つり合い法の計算手順を示す。ヤン ブ・ $h / 3$ 法による解を第 1 近似解として用い, 式 (10) の右辺, 左辺の $F$ が一致し, かつ式 (11)（第 7, 8 項 を省略）を満足させるまで繰返し計算する. 収束の判定は,

$$
\begin{aligned}
& \left|F_{r}-F_{l}\right| \leqq 0.01 \\
& \left|F_{r}-F_{i}\right| \leqq 0.01 \\
& \left|\tan \beta_{t}-\tan \beta_{r}\right| \leqq \Delta B
\end{aligned}
$$

*5 スライス間力 $(V, \Delta V, H, \Delta H)$ の伝達について, スペンサー ${ }^{9)}$ はスライス間力の合力の方向がすべてのスライ スで平行とみなし, またモルゲンステルンら ${ }^{6)}$ は $V / H=$ $\lambda \cdot f(x)$ ( $\lambda$ は定数, $f(x)$ は適当に選んだ関数, 図一9参照) とおいた，著者らは，余剰滑動力ベクトルがスライス間で伝 達される際にその位置と方向がスラスト線に一致すると仮定 するのが最も自然であると考えた。

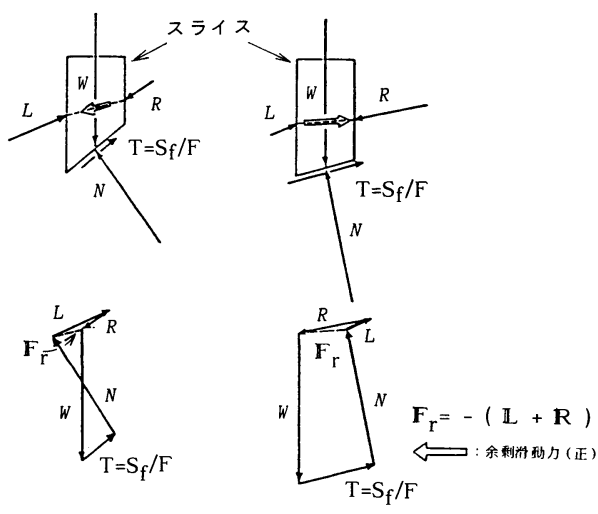

（1）余剩滑動力(正）（2）余剩顝力(負)

\section{図一3 余剩滑動力とカの多角形}

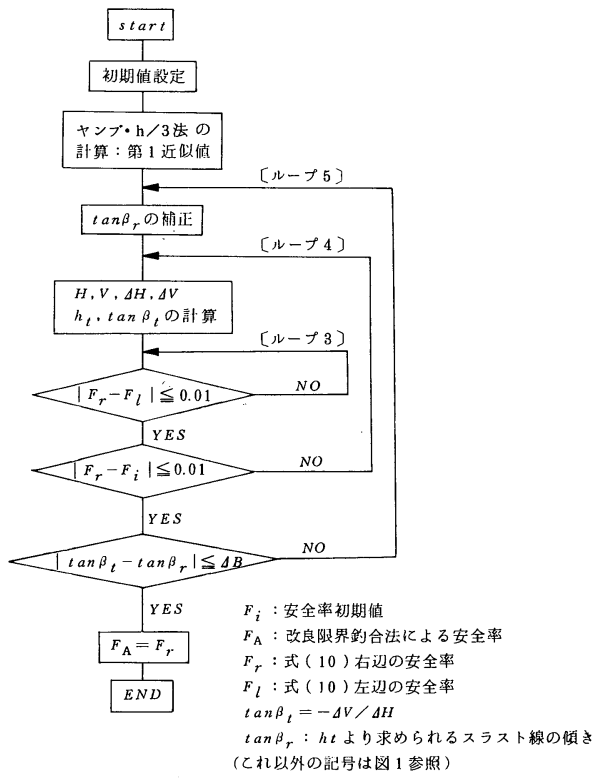

図一4 改良限界つり合い法計算手順

の 3 つの条件で行う.

ここに, $F_{i}$ : 初期設定安全率

$F_{r}:$ 式 $(10)$ 右辺の安全率

$F_{l}$ : 式 (10) 左辺の安全率

$\tan \beta_{t}=-\Delta V / \Delta H$

$\tan \beta_{r}: h_{t}$ より求められるスラスト線の傾き

$\Delta B$ : 収束許容誤差 (次項参照)

（３）改良限界つり合い法による解の性質

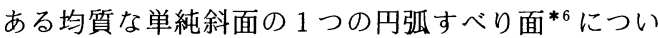

*6 改良限界つり合い法, ヤンブ・ $h / 3$ 法とも非円弧すべり 面に対して解析可能な計算方法であるが，簡単のためここで は円弧とした。なお，改良限界つり合い法は，ヤンブ・ $h / 3$ 法と同様に臨界円を求めることができるが，本論文ではあら かじめ設定した円弧に対して安全率を求めるにとどめた. 
て改良限界つり合い法で計算し, 解の性質を検討した. 表一1 に斜面の諸元および材料定数を示す. 表中 $\Delta B$ は

$$
\Delta B=\left|\left(-\frac{\Delta V}{\Delta H}\right)-\tan \beta_{r}\right|=\left|\tan \beta_{t}-\tan \beta_{r}\right|
$$

なる量で，収束許容誤差とよび，この值で解の収束判定 を行う. $\Delta B$ を小さく設定すると絽返し回数(図一 4 , ルー プ5)は急速に増え, 解を収束させることができないケ一 スもある，特に右端のスライスでは他の所よりも収束さ せることが難しい．そこで右端のスライスを他と区別し て, $\Delta B_{E}$ と表わし, $\Delta B=\Delta B_{E}$, あるいは $\Delta B<\Delta B_{E}$ の いずれの条件でも計算できるようにし，その影響につい ても検討した。

図一 5 は $\Delta B, \Delta B_{E}$ とも 0.01 (0.6 度) に設定して計 算したときの，スライス間力の大きさと方向，および作 用位置を示したものである. 繰返し回数（図一4,ルー プ 5）は実に 1870 回に達し, 事実上これよりも小さい 収束許容誤差で収束させることは困難である。なお，ス ライス(5)の左側のスライス面に引張力が㗢いているとい う結果であるが, 実際にはそれを期待することはできず, 引張クラックが発生するものと考えられるが9), 今回の 計算では，そこまでは考慮していない，図一6に，得ら れた余剩滑動力の分布を示す. 余剩滑動力の方向はスラ スト線の方向とまったく一致している. 各余剩滑動力の 向きから，スライス(3)，(4)は，それぞれの底面に㗢くせ ん断抵抗力だけではスライス自重による滑動力に抗する ことができず，その不足分が，スライス(1)，(2)および(5) によって補われている様子が理解できる.なお，余剩滑 動力の貸借は, すべり土塊全体でバランスすることはい うまでもない（式 (17)).

図一7 は, 図一5 と同じ円弧に対して, 収束許容誤差 を変えたときの安全率と, 収束までの繰返し回数（図一 4、ループ5）を示したものである. 図中には $\Delta B=\Delta B_{E}$, $\Delta B<\Delta B_{E}$ の両ケースについての結果を示した.いずれ も収束許容誤差を小さくすれば, 安全率は小さくなる.

次に, 収束許容誤差の最も大きい $\Delta B=0.3, \Delta B_{E}=0.4$ の結果と最も小さい $\Delta B=0.01, \Delta B_{E}=0.01$ の結果を比 較する. 両者による安全率には, 工学上問題にならない 0.012 の差しかないのに対して, 繰返し回数は約 23 倍 ( 1 1870/80) の違いがある.ここには示していないが, スライス間力, 余剩滑動力の分布にも大きな差はない. したがって, 収束許容誤差は 0.01 よりもかなり大きく てもよいと考えられる. 次に, 収束許容誤差を $\Delta B<$ $\Delta B_{E}$ にとることの影響について調べる. 図一7に示すよ うに, $\Delta B=\Delta B_{E}$ のケースに比べて, 安全率は最大でも 0.002 程度の差しかない.これに対して繰返し回数では 100〜200 回少なくなっている.
以上の結果から判断して, 収束許容誤差は

$$
\begin{aligned}
& \Delta B=0.1 \\
& \Delta B_{E}=0.2
\end{aligned}
$$

ととれば十分であると結論できる。しかし，特殊な形の 斜面では収束が一般に難しく，この基準をさらに緩めて 用いた。また，図一7中にはヤンブ・ $h / 3$ 法による安全 率も示したが, 安全率は 1.376 で, $\Delta B=0.01, \Delta B_{E}=$ 0.01 の場合よりも 0.014 大きいだけであった.

\section{表一1 計算斜面の諸元および材料定数}

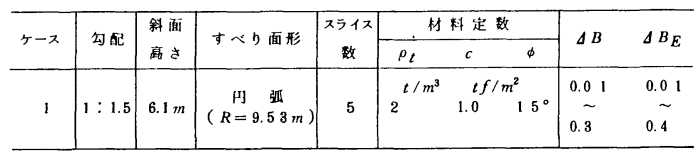

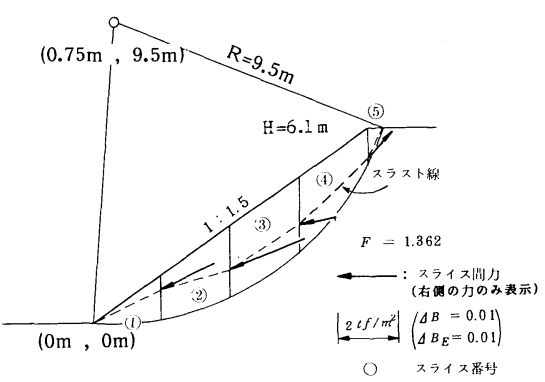

図一5 スライス間力の分布 (ケース 1$)$

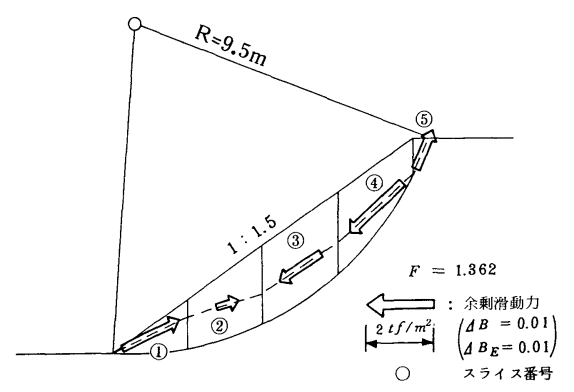

図一6 余剩滑動力の分布（ケース 1)
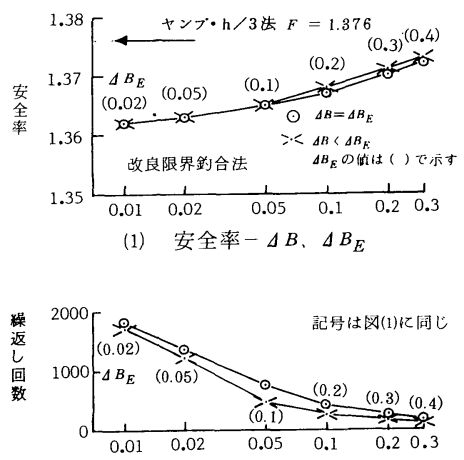

(2) 絽返し回数 $-\Delta B 、 \Delta B_{E}$

図一7収束許容誴差と安全率ならびに繰返し回数 (改良限界つり合い法) 
いずれにしても，ヤンブ・ $h / 3$ 法は改良限界つり合い 法による安全率のほほ上限の值を与えるが*7，その差は そう大きくないことから，実際上安全率に関してはヤン ブ・ $h / 3$ 法も改良限界つり合い法に近い精度を有する計 算法とみてよいだろう.

\section{3. 従来の安定計算法との比較}

\section{（1） 不静定次数と仮定}

それぞれの斜面安定計算法で用いられている条件式や つり合い式, 不足条件式数（不静定次数）および仮定に ついて検討しておくことは, 解の評価に関して重要であ る.

表一2 は各計算法の既知量, 未知量, 条件式および不 静定次数をまとめたものである*8. 不静定次数がゼロで あるのは無限斜面法だけで*9，その他の計算法では不静 定次数に応じて何らかの仮定の導入が必要であることが わかる．円弧すべり面にしか適用できないスウェーデン 法, 簡易ビショップ法が, 円弧中心に関するモーメント （表中８（3））を用いているのに対して，非円弧すべ り面に適用できる 4 つの計算方法は各スライスに関する モーメントのつり合い式（表中 $6(3)$ ) を用いている.

またヤンブ法, ヤンブ・ $h / 3$ 法, 改良限界つり合い法 の既知量, 未知量, 条件式および不静定次数はまったく 同じである M \& P 法は条件式が 1 つ少ないほかは同じ であることから，これらの解析手法は基本的に同じ立場 にあることが理解できる.

表一3 は各計算法で用いる仮定をまとめたものであ る. 表一 2 之比べると各計算法とも当然, 不静定次数之 仮定条件式数はまったく一致している，この表から各計 算法の性格について次のことがわかる.1つはスウェー デン法, ビショップ法のグループとそれ以外のグループ の本質的な違いである. 前者はスライス間力差の全部,

または一部をゼロと仮定しており, 当然, 解の誤差も大 きい，後者は主としてスライス間力の作用点および方向 に関する仮定を用いており，力に関する省略はない，し たがって適切な仮定によって，正しい解に近づくことが 期待できる.

もう 1 つは後者のグループの仮定の性格についてであ る. ヤンブ法, M \& P 法ではスライス間力の作用点あ *7 本論文で示した計算例はすべて改良限界つり合い法の安 全率に比べてヤンブ・ $h / 3$ 法の安全率が大きかった（表一4 参照).しかし， $\Delta B, \Delta B_{E}$ を大きくとらなければ収束しない ような斜面の場合で，わずかな差ではあるが逆転するケース もあった.

*8 モルゲンステルン・プライスの提案の特徵の 1 つは, 斜 面形状，すべり面，スラス卜線等を適切な関数に置き，より 一般化して斜面の安定問題を扱える点である. しかしその問 題は,ここでは考慮していない。

*9 ウェッジ法のうち三角土塊のすべりを仮定する方法も， 無限斜面法と同様に不静定次数はゼロである.
表-2 安定計算法の既知量, 未知量, 条件式, 不静定次数 11

\begin{tabular}{|c|c|c|c|c|c|c|c|}
\hline 安定計算法 & $\begin{array}{l}\text { 舞面琺 } \\
\end{array}$ & 砥 $x$-y法 & 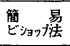 & ヤンブ法 & M\&P法 & $\begin{array}{l}\text { py } \\
\text { h/3 }\end{array}$ & 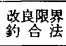 \\
\hline 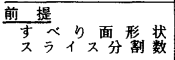 & ${ }_{1}{ }_{1}$ 面 & $\mathrm{m}_{\mathrm{n}}$ 㧓 & $\mathrm{m}_{\mathrm{n}}$ 坬 & 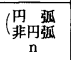 & (罪 & 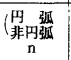 & 罪孤 \\
\hline$\frac{\text { 既知量 }}{1}$ & 1 & $\mathrm{n}$ & $\mathrm{n}$ & $\mathrm{n}$ & $\mathrm{n}$ & $\mathrm{n}$ & $\mathrm{n}$ \\
\hline 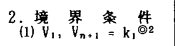 & - & 2 & 2 & 2 & 2 & 2 & 2 \\
\hline (2) $\mathrm{H}_{1}, \mathrm{H}_{n+1}=\mathrm{k}_{2} \oplus 2$ & - & 2 & 2 & 2 & 2 & 2 & 2 \\
\hline (3) $h_{2}, h_{n_{n}, 1}=k_{3} \odot 2$ & - & - & - & 2 & 2 & 2 & 2 \\
\hline 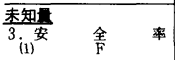 & 1 & 1 & $\mathrm{n}$ & $\mathrm{n}$ & $\mathrm{n}$ & $\mathrm{n}$ & $\mathrm{n}$ \\
\hline 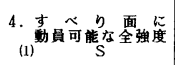 & 1 & $\mathrm{n}$ & $\mathrm{n}$ & $\mathrm{n}$ & $\mathrm{n}$ & $\mathrm{n}$ & $\mathrm{n}$ \\
\hline${ }^{5}$ (1) スライスに湡 & 1 & $\mathrm{n}$ & $\mathrm{n}$ & $\mathrm{n}$ & $\mathrm{n}$ & $\mathrm{n}$ & $\mathrm{n}$ \\
\hline (2) & 1 & $\mathrm{n}$ & $\mathrm{n}$ & $\mathrm{n}$ & $\mathrm{n}$ & $\mathrm{n}$ & $\mathrm{n}$ \\
\hline (3) & - & $n-1$ & - & - & - & - & - \\
\hline (4) & - & $n-1$ & - & - & - & - & - \\
\hline$\Delta \mathrm{v}$ & 1 & - & $\mathrm{n}$ & $\mathrm{n}$ & $\mathrm{n}$ & $\mathrm{n}$ & $\mathrm{n}$ \\
\hline$\Delta \mathrm{H}$ & 1 & - & $\mathrm{n}$ & $\mathrm{n}$ & $\mathrm{n}$ & $\mathrm{n}$ & $\mathrm{n}$ \\
\hline (7) & - & - & - & $n-1$ & $n-1$ & $n-1$ & $n-1$ \\
\hline 末 知 量 合 & 6 & $5 n-1$ & $6 \mathrm{n}$ & $7 n-1$ & $7 n-1$ & $7 n-1$ & $7 n-1$ \\
\hline 䀜件式 & & & & & & & \\
\hline 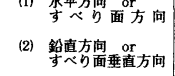 & $\begin{array}{l}1 \\
1\end{array}$ & $\mathrm{n}$ & $\mathrm{n}$ & $\mathrm{n}$ & $\mathrm{n}$ & $\mathrm{n}$ & $\mathrm{n}$ \\
\hline (3) モーメント & - & - & - & n & $\mathrm{n}$ & $\mathrm{n}$ & $\mathrm{n}$ \\
\hline 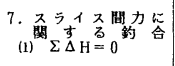 & 1 & - & - & 1 & $\dot{-}$ & 1 & 1 \\
\hline (2) $\Sigma \Delta V=0$ & 1 & - & - & - & - & - & - \\
\hline 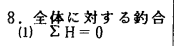 & - & - & - & - & - & - & - \\
\hline (2) $\Sigma V=0$ & - & - & - & - & - & - & - \\
\hline (3) $\Sigma M=0$ & - & $(1)^{\oplus 8}$ & 1 & - & - & - & - \\
\hline${ }^{9}$ (1) 㤝クーロ喥則 & 1 & $\mathrm{n}$ & $\mathrm{n}$ & $\mathrm{n}$ & $\mathrm{n}$ & $\mathrm{n}$ & $\mathrm{n}$ \\
\hline 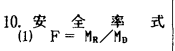 & - & 1 & - & - & - & - & - \\
\hline (2) $\mathrm{F}=\mathrm{S} / \mathrm{T}$ & 1 & - & $\mathrm{n}$ & $\mathrm{n}$ & $\mathrm{n}$ & $\mathrm{n}$ & $\mathrm{n}$ \\
\hline (3) $F_{1}=F_{2}=\cdots=F_{n}$ & - & - & $n-1$ & $n-1$ & $n-1$ & $n-1$ & $n-1$ \\
\hline 集件 式数 合㖕 & 6 & $3 n+1$ & $5 n$ & $6 n$ & $6 n-1$ & $6 \mathrm{n}$ & $6 \mathrm{n}$ \\
\hline 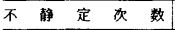 & 0 & $2 n-2$ & $n$ & $n-1$ & $n$ & $n-1$ & $n-1$ \\
\hline
\end{tabular}

表一3 各安定計算法で用いる仮定

\begin{tabular}{|c|c|c|c|}
\hline 解折法 & すべり面形状 & 仮 & 仮定条件式数 \\
\hline スウメーデン & 円 & $\begin{array}{l}V=0 \\
H=0\end{array}$ & $\begin{array}{r}n-1 \\
n-1 \\
\text { 計 } \\
\end{array}$ \\
\hline $\begin{array}{l}\text { 简易 } \\
\text { ビショョナ }\end{array}$ & 円 & $\Delta v=0$ & $n$ \\
\hline+27 & $\left(\begin{array}{l}\text { 円 } \text { 呱 } \\
\text { 非丹咋 }\end{array}\right.$ & $\begin{array}{l}h_{t} \text { 老適切に仮定し、「適 } \\
\text { 切な解」を選ふ。 }\end{array}$ & $n-1$ \\
\hline$M \quad \& \quad P$ & 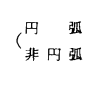 & 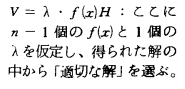 & $\begin{array}{l}n-1 \\
\frac{1}{\text { 計 } n}\end{array}$ \\
\hline ヤンブ・h/3 & 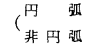 & $h_{t}=h_{s} / 3$ & $n-1$ \\
\hline 政良限界釣合 & $\left(_{\text {非 巴 弧 }}^{\text {巴 }}\right.$ & $\begin{array}{l}\Delta V / \Delta H=-\tan \beta_{t} \\
\text { (上端おるいは端のス } \\
\text { ライスは仮定加不要) }\end{array}$ & $n-1$ \\
\hline
\end{tabular}

るいは作用方向を適当に仮定し, 解の中から「適切な解」 を選ぶという方針をとっている。 そこでホイットマンら は「適切な解」として,

(1) $\phi>\phi_{\mathrm{req}}$

ここに， $\phi_{\mathrm{req}}$ : スライス側面に動員される摩擦角, 


$$
\phi_{\text {req }}=\tan ^{-1}\left(\frac{V-c \cdot h_{s}}{H}\right)
$$

$V, H$ : スライス間力の鉛直, 水平成分

$$
h_{s}: \text { スライス高さ }
$$

(2) スラスト線の流れが適切である.

の 2 つを挙げた ${ }^{10)}$. スラスト線（すなわち $h_{t}$ の位置） についてのヤンブの仮定は2.（1）にすでに示した.

しかし, 実際にこのような「基準」で,「適切な解」 かそうでないかを判断することが難しいことは想像にか たくない. 一方ヤンブ・ $h / 3$ 法, 改良限界つり合い法で は, 一応妥当と思われる仮定を導入し，それによって妥 当な解を唯一的に得ようとするものである.

\section{（2）改良限界つり合い法と M \& P 法との比較}

図一8 はホイットマンらが $\mathrm{M} \& \mathrm{P}$ 法を用いて安定計 算を行ったモデル斜面の形状と材料定数である ${ }^{10)}$. 図一 9 は $f(x), \lambda$ を変えて得られた 4 つの解である(ただし, $\lambda$ 值は 4 ケース共不明).このうち図一 9 ( 1 ),（2）に 示すものは「適切な解」と判断され, また図 (3), (4) に示すものは $\phi_{\mathrm{req}}$ が大きすぎること，スラスト線位置 が適切でないことから，「適切でない解」と判断された ものである、したがってこのすべり面の安全率は，「適 切な解」の図（1），（2）の 1.59〜1.61 となる.

図一10（1)，（2）は改良限界つり合い法による結果 である.スラスト線の形は, 図一9 の中では (2) の結 果によく似ている， $\phi_{\text {req }}$ は図一10（2）に示したが，90 〜 0 で, ホイットマンらが得た結果よりも小さいが, いずれにしても $\phi>\phi_{\text {req }}$ を満足する（ただし，引張域は 無視する)，安全率は 1.630 で，M＆P 法による結果よ りもやや大きいが, 工学上問題にならない差である. M $\& \mathrm{P}$ 法との比較が可能な他の適当な計算例がみつから なかったので, 計算結果によるこれ以上の検討はできな いが, 上述の比較で, M \& P 法が多くの試行と engineering judgement を要するのに対し, 改良限界つり 合い法はより簡単に, 妥当な結果を得ることができるこ とが理解されよう*10.

\section{（３）４つの方法による安全率の比較}

スウェーデン法, 簡易ビショップ法, ヤンブ・ $h / 3$ 法 および改良限界つり合い法を用いて, 浸透流のない 4 ケースの例題を計算して安全率を比較した. モデル斜面 は図一8のケースと, 図一11に示す 3 ケースである（す ベり面はいずれものり先破壊で, すべり面の半径と中心

*10 M \& P 法および改良限界つり合い法の両方とも, その 基本式として表一 2 中の $6(1) ，(2)$ ，（3）を用いるので基 本的には仮定したスラスト線位置の違いが求める諸量 $(F$, $\left.F_{i}, H_{i}, \cdots\right)$ の違いに反映する. したがってスラス卜線位置に 極端な差がない限り, 原理的に両者の解に大きな差は生じ得 ない.このことはヤンブ・ $h / 3$ 法についても同様である.

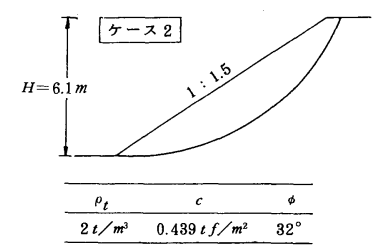

図一8 単純 $(1: 1.5)$ 斜面 (ケース 2$)$
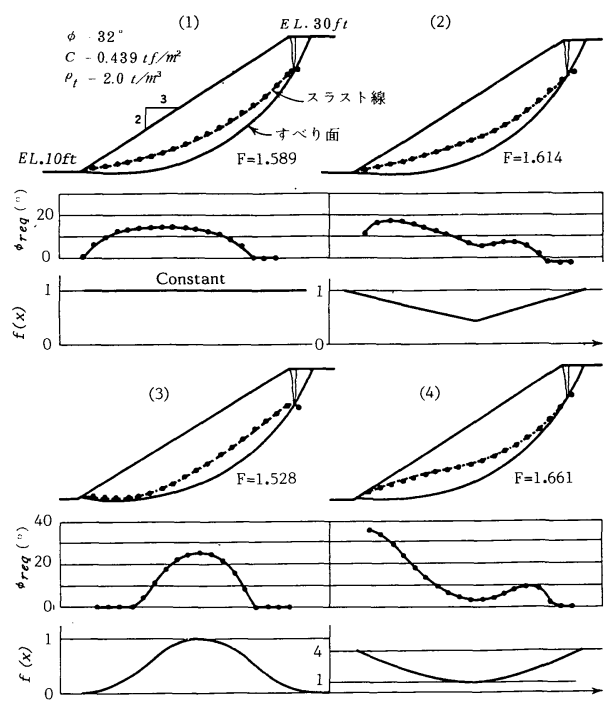

図一9 モルゲンステルン・プライス法 (ホイットマンらによる) $)^{10)}$

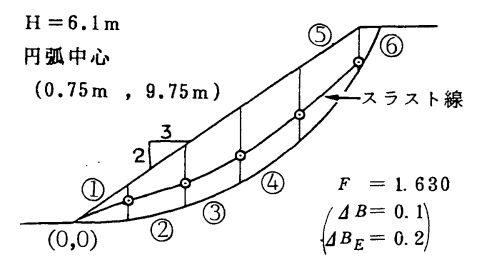

(1) スラスト線

○ スライス番鸟

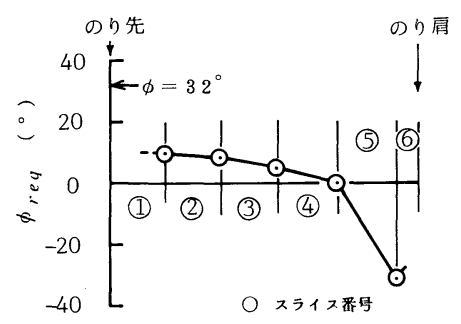

(2) $\phi_{r e q}$ - スライス番号

図一10 改良限界つり合い法 (ケース 2)

位置については図一12〜15に示す). 表一4に結果を示 す. 安全率の最小值および最大值は, それぞれスウェー デン法およびヤンブ・ $h / 3$ 法によって得られた. 改良限 界つり合い法の結果はヤンブ・ $h / 3$ 法の值よりもいずれ 
もわずかに小さくなった.

スウェーデン法では $V=0, H=0$ の仮定を用いるた め, 特に勾配の急なすべり面上の垂直力を小さく見積も り, その結果せん断抵抗を過小に評価し, 過小な安全率 を与えた。 また， $\Delta V=0$ と仮定する簡易ビショップ法 の計算では, スウェーデン法とヤンブ・ $h / 3$ 法の結果の ほぼ中間の値を与えた。

表一5にスウェーデン法, 簡易ビショップ法による安 全率の, 改良限界つり合い法の安全率に対する比を示す. スウェーデン法では 10〜15\%，簡易ビショップ法では 5〜7\% だけ安全率が改良限界つり合い法に比べて小さ い. ビショップはあるモデル斜面について計算し，「簡 易ビショップ法の安全率がビショップの厳密法によるよ りも約 $5 \%$ 小さい」と, またホイットマンらは M \& $\mathrm{P}$ 法と比較して，「簡易ビショップ法は $7 \%$ 以下の誤差を もっている」と述べている ${ }^{10)}$. 表に示すように，簡易ビ ショップ法の安全率が改良限界つり合い法に対してちょ うど 5〜7\% 小さくなっていることから，逆にビショッ プの箃密法, M\&P 法は改良限界つり合い法と同等の 安全率を与え得る方法*11 であることがわかる.

\section{（4）提案する 2 方法によるスライス間力，余剩滑動 力の検討}

前節と同じ 4 ケースのモデル斜面について，改良限界 つり合い法およびヤンブ・ $h / 3$ 法によって得られるスラ イス間力, 余剰滑動力, スラスト線を比較したものが図 一12〜15である。単純斜面（ケース 2 ; 図-12）ではス ラスト線に大きな差はなく，スライス間力，余剰滑動力 とも似かよった結果が得られた。 凸斜面（ケース 3 ; 図 一13）では，スライス間力は比較的似かよってはいるも のの，ヤンブ・ $h / 3$ 法による余剩滑動力の分布は，スラ スト線に対してばらつき，力の絶対値も大きい，凹およ び小段付斜面（ケース 4，5，図-14，15）では両計算 法の結果の違いがさらにはっきりしている．特にヤン ブ・ $h / 3$ 法による余剩滑動力の分布には方向性がなく, 力の流れが自然でない。 なお，ケ一ス $3,4 ， 5$ では，斜 面形状が特殊で改良限界つり合い法の解の収束が悪く, 収束許容誤差を大きくとって計算せねばならなかった。 そのため余剩滑動力の方向とスラスト線の方向は必ずし も一致していない.

さて，以上の改良限界つり合い法の結果は，ヤンブゃ ホイットマンらが示した「解が適切であるための条件」 (2. (1)，3.(1)) をよりどころに考えるならば，いず れも適切な解と判断される.ヤンブ・ $h / 3$ 法による解は,

*11 M \& P 法は唯一的な解を与えるものでないから (3. (2)), 与えるとはいえない。 また，ビショップの厳密法によ る解析法, あるいは計算例については, 著者らの知る限り報 告されておらず，これ以上本法との比較はできない。

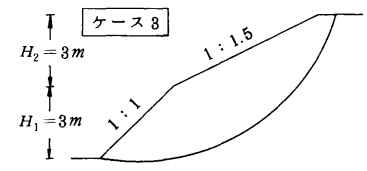

（1）凸 (1:1.1:15) 斜面

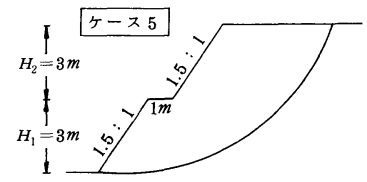

(3) 小段付 $(1.5: 1)$ 斜面

図一11 モデル斜面 (ケース $3 ， 4 ， 5)$

表一4 安全率の比較

\begin{tabular}{c|c|c|c|c}
\hline ケース & スウエーデン & $\begin{array}{c}\text { 简 易 } \\
\text { ピショツプ }\end{array}$ & $\begin{array}{l}\text { ヤンブ・ } \\
\mathrm{h} / 3\end{array}$ & $\begin{array}{c}\text { 改 良 } \\
\text { 限界釣合 }\end{array}$ \\
\hline $2^{\star}$ & 1.43 & 1.54 & 1.63 & 1.63 \\
3 & 1.51 & 1.65 & 1.77 & 1.76 \\
4 & 1.19 & 1.28 & 1.36 & 1.34 \\
5 & 1.21 & 1.33 & 1.41 & 1.40 \\
\hline
\end{tabular}

* $\mathrm{M} \& \mathrm{P}$ 法による「ケース 2 」斜面の安全率は $1.59 \sim 1.61$ ( 3.2 参照)。

\begin{tabular}{c|l|l} 
表一 5 & \multicolumn{3}{|c}{$F_{S} / F_{A}, F_{B} / F_{A}$ の比* } \\
\hline ケース & $\mathrm{F}_{\mathrm{S}} / \mathrm{F}_{\mathrm{A}}$ & $\mathrm{F}_{\mathrm{B}} / \mathrm{F}_{\mathrm{A}}$ \\
\hline 2 & $87.7(\%)$ & $94.5(\%)$ \\
3 & 85.8 & 93.8 \\
4 & 88.8 & 95.5 \\
5 & 86.4 & 95.0 \\
\hline
\end{tabular}

* F S : スウエーデン法による安全率 $\mathrm{F}_{\mathrm{B}}$ ：簡易ビショップ法による安全事 $\mathrm{F}_{\mathrm{A}}$ ：改良限界釣合法に上る安全率

スライス間力, 特に余剩滑動力については適切でない分 布を与えるケースもあり，この点は改良限界つり合い法 に比べて合理的とはいえない. しかし，安全率の值に関 しては十分満足できるものである。

\section{4. 結 論}

本研究で得られた主な結論は次のとおりである.

（1） 円弧および非円弧すべり面に適用できるヤン ブ・h/3 法および改良限界つり合い法の 2 つの斜面安定 計算法を新しく提案した. 両計算法とも基礎式としてス ライスのすべり面方向とそれに垂直な方向のつり合い 式，および $N$ の作用点 $m$ (図一1参照) に関するモ一 メントのつり合い式を用いる．前者は「スライス間力の 作用高さはスライス高さの $1 / 3$ である」，後者は「余剩 滑動力の方向はスラスト線の方向に一致する」の仮定を 用いた。ここに余剩骬動力は，1つのスライスに㗢くス ライス間力のベクトル和と同じ大きさで，逆向きの力と 定義した。 
（2）改良限界つり合い法による解は収束計算によっ て得られるが, そのとき, 収束許容誤差を小さくしてい くと安全率はわずかに小さくなっていくが，収束のため の繰返し回数は急増する.この点を考えて適当な収束許 容誤差の值を示した。

（３） ヤンブ・ $h / 3$ 法による安全率は, 改良限界つり 合い法による解よりもわずかに大きく（計算例では 0.014 以下), ほぼ改良限界つり合い法による安全率の
上限値となる．しかし，その差は小さくて工学上問題に ならず，両者はほぼ同じ安全率を与えるとしてよい。

（4）従来用いられてきた無限斜面法, スウェーデン 法, 簡易ビショップ法, ヤンブ法, モルゲンステルン・ プライス法 ( $\mathrm{M} \& \mathrm{P}$ 法) および新たに提案したヤンブ . $h / 3$ 法, 改良限界つり合い法について, 安定計算等で用 いられている条件式, つり合い式を調へ，不足条件式数 （不静定次数）とそれに対する仮定を明らかにした.

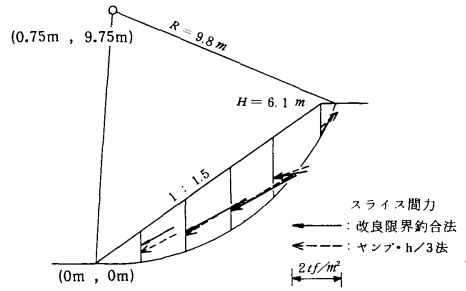

(1) スライス間力

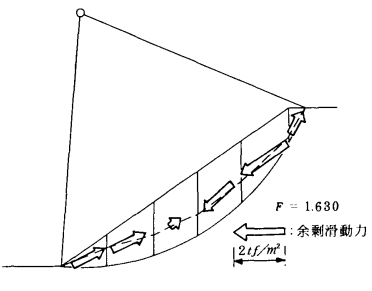

（2）余剩滑動力

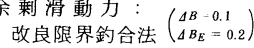

図一12 1:1.5 斜面（ケース 2 )

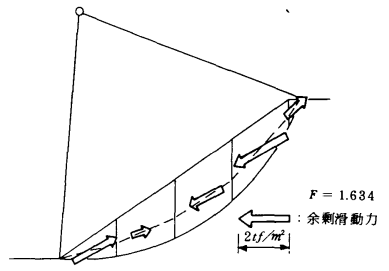

(3) 余剩滑動力： ヤンプ・h/3法

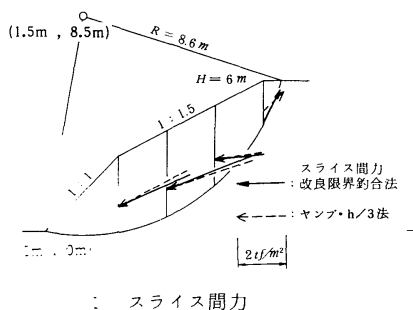

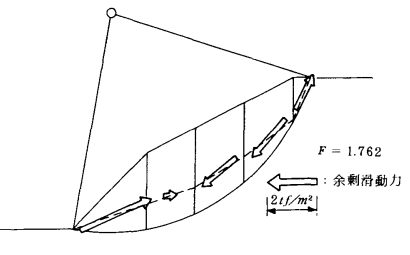

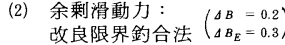

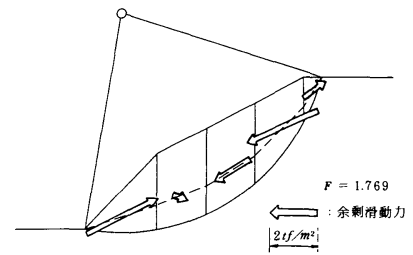

(3) 余剩滑動力: ヤンプ・ $\mathrm{h} / 3$ 法

図一13 凸 $(1: 1,1: 1.5)$ 斜面（ケース 3$)$

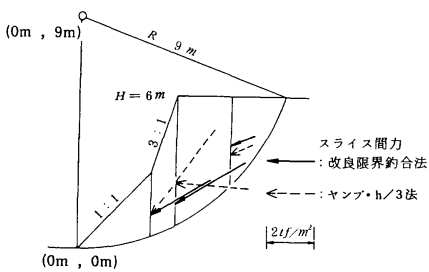

(1) スライス間力

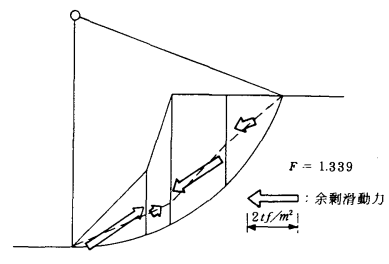

（2）余剩滑動力： $\left(\begin{array}{l}\Delta B=0.2 \\ \Delta B_{5}=0.3\end{array}\right)$

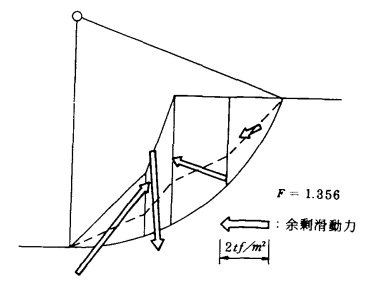

(3) 余剩滑動力 ヤンブ・h/3法

図一14 凹 $(1: 1,3: 1)$ 斜面 (ケース 4)

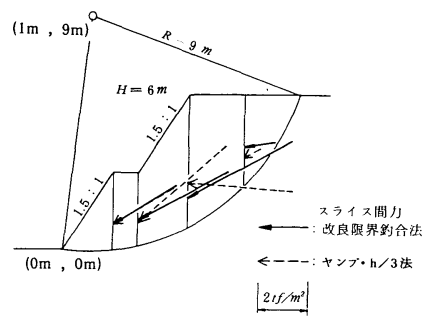

(1) スライス間力

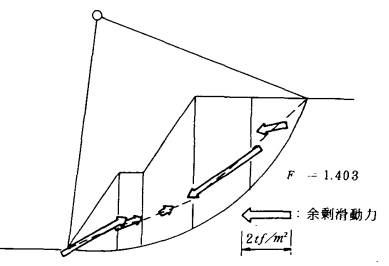

（2）余剩滑動力：
改良限界釣合法 $\left(\begin{array}{l}\Delta B=0.3 \\ \Delta B_{E}=0.4\end{array}\right)$

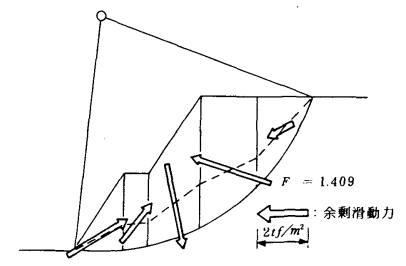

（3）余剩滑動力: 
（5）改良限界つり合い法による解を， M\&P 法に よるホイットマンらの「適切な解」と比較したところ, スラスト線, 安全率ともほぼ一致した結果が得られた。 改良限界つり合い法は M\&P 法に比べて, より簡単に, 唯一的に妥当な結果を与える.

（6）４ケースのモデル斜面（浸透流を考えない）に 対して, スウェーデン法, 簡易ビショップ法, ヤンブ・ $h / 3$ 法, 改良限界つり合い法で計算した安全率を比較し た結果, 安全率はいずれのケースでも

スウェーデン法く簡易ビショップ法く改良限界つり合 い法

となった．改良限界つり合い法を基準に考えると，ス ウェーデン法による安全率は 10１5％，簡易ビショッ プ法による安全率は $5 \sim 7 \%$ 小さくなった.

（7）改良限界つり合い法は，ヤンブ・ $h / 3$ 法に比べ て, はるかに自然で妥当なスライス間力, 余剩滑動力を 与える.しかし，両者はほぼ同じ安全率を与えることか ら，ヤンブ・ $h / 3$ 法は非円弧すべり面にも適用できる精 度のよい実用計算法と位置づけることができる.

謝 辞：計算手法の開発に協力された元・大阪市立 大学学部生（現・基礎地盤コンサルタンツ(株)）庄司 岳雄氏，および解析法について討論して頂いた大阪市立 大学 園田恵一郎教授に感謝の意を表します.

\section{参 考 文 献}

1) Fellenius, W. : Calculation of the Stability of Earth Dams, Second Congress on Large Dams, pp. 445 462, 1936.

2) Bjerrum, L. and Flodin, N. : The Development of Soil Mechanics in Sweden, 1900-1925, Geotech., Vol.10, pp. 1 18, 1960.

3) Taylor, D. W. : Stability of Slopes (chap. 16), -Foundations of Soil Mechanics, John Wiley \& Sons, pp. 406 479, 1948.

4) Bishop, A.W. : The Use of the Slip Circle in the Stability Analysis of Slopes, Geotech., Vol.5, pp.7 17, 1955.

5) Janbu, N. : Earth Pressure and Bearing Capacity Calculations by Generalized Procedure of Slices, The 4 th ICSMFE, Vol. 2, pp. 207 212, 1957.

6) Morgenstern, N.R. and Price, V.E. : The Analysis of the Stability of General Slip Surfaces, Geotech., Vol. 15, pp. 79 93, 1965.

7）望月秋利：三笠正人：フィルダムの安定解析法, 土と基 礎, Vol. 32-4, pp.19 26, 1984.

8) Janbu, N. : Slope Stability Computations, Embankment-Dam Engineering, John Wiley \& Sons, pp. 47 86, 1973.

9) Spencer, E. : Effect of Tension on Stability of Embankments, ASCE, SM 5, pp.1159 1173, 1968.

10) Whitman, R. V. and Bailey, W. A. : Use of Computers for Slope Stability Analysis, ASCE, SM 4, pp.475 498, 1967.

(1986.1.20 - 受付) 